\title{
Cost Comparison between Stone Mastic Asphalt and Asphalt Concrete Wearing Course
}

\author{
Salihudin Hassim, Rohimah Khoiriyah Harahap, Ratnasamy Muniandy, \\ Mohd. Razali Abd. Kadir and Ahmad Rodzi Mahmud \\ Department of Civil Engineering, Faculty of Engineering, University Putra Malaysia \\ 43400 Serdang, Selangor, Malaysia
}

\begin{abstract}
Stone Mastic Asphalt (SMA) technology has been introduced to Malaysia since the 1990's. Since then, several trials had lain projects had been initiated for the purpose of evaluating the mix on local road condition. However, the acceptability of SMA is still quite discouraging among the local road authorities. This setback is probably due to the misconception on the high initial cost of SMA. But recently, this claim has been challenged. A Malaysian study revealed that the construction cost of SMA is $10 \%$ to $15 \%$ less than the conventional mix. Hence, this study aims to compare the construction cost of SMA and ACW20. Initially, a population study on 27 SMA and ACW20 projects was initiated with the assistance of a standardized questionnaire. The result indicated that the construction cost of SMA is indeed significantly higher than ACW20. The study recommended that an economic construction cost of SMA is achievable if the cost of material and thickness of the laid surfacing are properly managed.
\end{abstract}

Key words: Stone mastic asphalt, construction cost, cost comparison

\section{INTRODUCTION}

The concept of Stone Mastic Asphalt (SMA) has been introduced to Malaysia road authorities as early as the 1990's. Since then, several trials had lain projects had been initiated for the purpose of studying the durability and stability of SMA ${ }^{[1]}$. However, the acceptability of SMA is quite discouraging among the road authorities. As a result Malaysia has yet to produce its own standard specification for the design mix of SMA.

The main reason behind this is probably due to the misconception on the high cost of SMA. For example, a United States study reported that the initial cost of SMA is $20 \%$ to $25 \%$ more than the conventional mix ${ }^{[2]}$. However, this claim contradicts with a Malaysian study on the initial cost of SMA. According to a research conducted by University Putra Malaysia ${ }^{[1]}$, the construction cost of SMA is approximately 10 to $15 \%$ cheaper than the conventional mix with an extended pavement life by 1.5 times. This is achieved because the thickness of the laid SMA surfacing is $30 \%$ less than the conventional wearing course layer. From the discussion above, it is clear that the ambiguous cost of SMA must be resolved through scientific research. Another important question is how to make SMA economically viable for implementation since the mechanical properties of the mix are found far superior than the conventional surfacing material.

Wearing course materials: Wearing Course or Surface Course is referring to the top layer of either a flexible or a composite pavement. It provides a uniform carriage way for vehicles to run on. Currently, there are numerous types of surfacing materials. However this particular research focused on Stone Mastic Asphalt (SMA) with and without fiber, as well as Asphalt Concrete Wearing Course with $20 \mathrm{~mm}$ nominal size aggregate (ACW20).

Stone mastic asphalt: Stone Mastic Asphalt is a very high stone content, gap-graded mixture with high binder content. It contains a continuous coarse aggregate skeleton that is able to carry traffic load and provides good deformation resistance ${ }^{[3]}$. Based on past research on SMA by Brown et al. ${ }^{[4]}$, Vasudevan et al. ${ }^{[5]}$, Muniandy et al. ${ }^{[6]}, \mathrm{Yu}^{[2]}$ and Mohamad Razali and Zulakmal $^{[7]}$, it is clear that the mechanical properties of SMA are far superior than the conventional mix, making it more favorable for application. However, there are a few contradictory studies on the economic viability of SMA as reported by University Putra Malaysia $^{[1]}$ and by $\mathrm{Yu}^{[2]}$.

Asphalt concrete wearing course (ACW20): Asphalt Concrete Wearing Course (ACWC) is a continuously graded mixture with small maximum particle sizes. Its mixture of mineral aggregate, filler and bituminous binder forms an interlocking structure that contributes to the strength and performance of the design mix. ACWC is commonly used throughout the world including Malaysia. Based on current practice, the accepted ACWC design mix of Malaysian highway is ACW20.

Corresponding Author: Rohimah Khoiriyah Harahap, Department of Civil Engineering, Faculty of Engineering,

University Putra Malaysia, 43400 Serdang, Selangor, Malaysia 
Methods for estimating the construction cost of pavement: Generally, past researches have recorded five (5) probabilistic methods for forecasting the construction cost of pavement. They are as follows:

1. Unit rates of construction: Such as dollars per mile by highway type. It has been used in the United States for short-term construction cost estimation as recorded by Hartgen and Talvitie ${ }^{[8]}$ as well as Stevens ${ }^{[9]}$. In the long run this method is considered unreliable and inaccurate as it disregarded variation in the site conditions especially for projects of different locality.

2. Extrapolation of past trends or time-series analysis: This method allows all the costs to collapse in a single overall expression, for examples Building Construction Index or Construction Cost Index as suggested by Koppula ${ }^{[10]}$ and Hartgen et al. ${ }^{[11]}$. Thus, it is only suitable for short-term forecasting as it relied on past cost data.

3. Statistical model: This includes Regression Analysis, which uses the significant cost factors to predict the construction cost, as reported by Wilmot and Cheng ${ }^{[12]}$. The relationship between construction cost and these factors is based on past project records. Typically, regression models have been used to estimate the cost of individual highway construction contracts based on studies by Williams ${ }^{[13]}$ as well as Jin and $\mathrm{Wei}^{[14]}$. According to Wilmot and Cheng ${ }^{[12]}$, this is the only probabilistic estimating method that provides reliable long-term prediction.

4. Hybrid of regression analysis and neural network: Which has been used to predict the construction cost of a completed highway project using bidding data. The result proved that regression model using natural $\log$ of the low bid produced the best result $^{[15]}$.

5. Neural network: This method was used to estimate the construction cost of highway projects based on past project data found in Newfoundland as initiated by Hergazy and Ayed ${ }^{[16]}$. At the same time, Adeli and $\mathrm{Wu}^{117]}$ also applied this technique for forecasting the construction cost of reinforced concrete pavements.

Selection of the suitable estimating technique: Prior researcher such as Herbsman ${ }^{[18]}$ as well as Wilmot and Cheng ${ }^{[12]}$ quoted that the most influential items affecting the construction cost of premix are material, labor and equipment. Meanwhile, other researchers such as Morrison ${ }^{[19]}$, Ashworth ${ }^{[20]}$, Akintoye and Fitzgerald $^{[21]}$ as well as Oberlender and Trost ${ }^{[22]}$ revealed that there are controllable and uncontrollable factors, which may affect the accuracy of an estimate. Therefore, it is wise to select the most suitable and efficient estimating technique for quantifying the construction cost of SMA and ACW20.

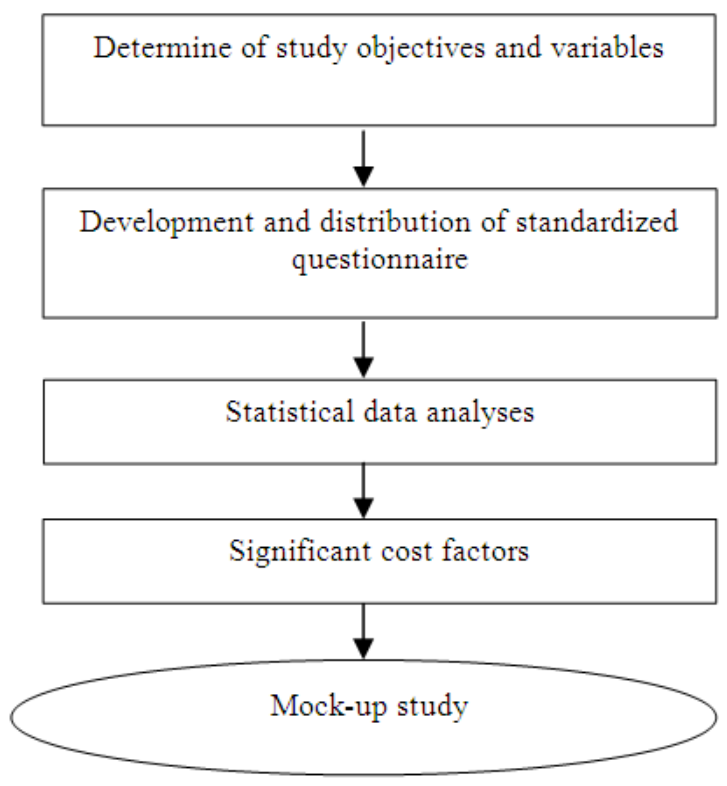

Fig. 1: The research methodology process

Past studies also indicated that statistical analysis is the most favored alternative estimating method used to estimate the construction cost of highway. This is probably due to the numerous merits found in this probabilistic estimating technique, as recorded by Koppula $^{[10]}$, Hartgen et al. ${ }^{[11]}$, Williams ${ }^{[13]}$, Wilmot and Cheng ${ }^{[12]}$ as well as Jin and Wei ${ }^{[14]}$. The application of exploratory data analysis (EDA) for describing cost data as well as to characterize the differences among the studied groups. Thus, the construction cost of SMA and ACW20 will be compared via EDA, in order to determine the most economical solution. While the significant cost elements will be identified by regression analysis.

\section{MATERIALS AND METHODS}

The basic research methodology process of this study is illustrated in Fig 1. Initially, preliminary data collection and literature survey are carried out in order to develop and determine the study objectives and variables.

Then, standardized questionnaire of the study is developed and distributed to the targeted population frame, which are quarries producing and constructing SMA and ACW20 in the Selangor state. Selangor state, which is located in the central region of Peninsular Malaysia is selected as it has the highest quarry population in Malaysia. The questionnaires will be distributed either through personal interview, facsimile or electronic mail. These raw data are then analyzed via Statistical Package for Social Science version 11.5 (SPSS) using statistical methods including frequency distribution, exploratory data analysis (EDA) and multiple regression analysis (MRA). 
Result of the EDA will determine whether the construction cost of SMA is significantly higher than ACW20. Meanwhile, the output of MRA will suggest the significant factors in the construction cost of SMA and ACW20. A mock-up study is then performed to test the relationship between the significant factors and the construction cost of two studied materials.

\section{RESULTS}

The standardized questionnaire has successfully obtained vital information on material cost/ton, plant cost/ton, transportation cost/ton, equipment cost/ton and labor cost/ton, which represented the independent variables of this study. Aside from that, a separate section of the questionnaire also managed to collect data on the construction cost per meter square, which represented the dependent variable. On the other hand, the population frame of this research consisted of 10 cases of SMA projects and 17 cases of ACW20 projects, which are considered as a good sampling design as it includes $100 \%$ of the SMA-producers in Selangor and $89 \%$ of the ACW20-producers in
Selangor. The distribution of the obtained questionnaires comprised of $48 \%$ response from faceto-face interviews (13 cases), $41 \%$ response from personally administered questionnaires (11 cases) and the balanced $11 \%$ response from electronic mail (3 cases).

Statistical analyses: Initially, the characteristics of the respondents and quarries were analyzed by frequency distribution and the result indicated that the study consisted of well-validated data. Secondly, the output of exploratory data analysis (EDA) suggested that the construction cost per meter square of SMA is significantly higher than ACW20. According to Table 1, the mean for the construction cost/meter square of SMA is $61 \%$ more than ACW20. This result is also supported by Table 2, which suggested that $50 \%$ of the construction cost/meter square of SMA projects ranges between RM 16.38 to RM 18.20 per meter square. This is by far exceeded the construction cost/meter square of $50 \%$ of ACW20 projects, which only priced between RM 9.71 to RM 11.63 per meter square.

Table 1: Descriptive table

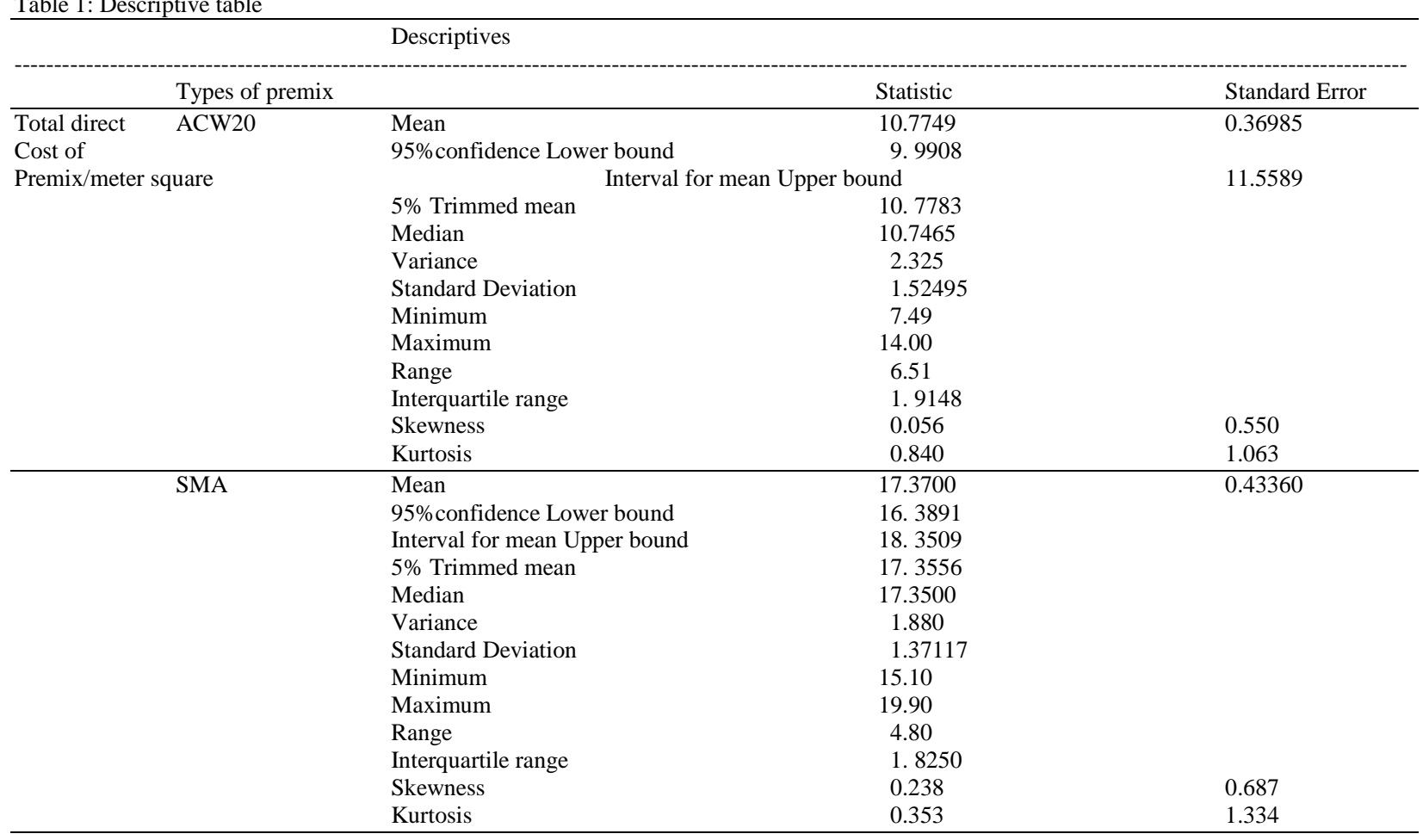

Table 2: Percentile table

\begin{tabular}{|c|c|c|c|c|c|c|c|c|c|}
\hline & & \multirow{2}{*}{$\begin{array}{l}\text { Type of premix } \\
\text { produced }\end{array}$} & \multicolumn{7}{|c|}{ Percentiles } \\
\hline & & & 5 & 10 & 25 & 50 & 75 & 90 & 95 \\
\hline $\begin{array}{l}\text { Weighted Average } \\
\text { (Definition 1) }\end{array}$ & $\begin{array}{l}\text { Total direct cost } \\
\text { of premix/meter square }\end{array}$ & $\begin{array}{l}\text { ACW20 } \\
\text { SMA }\end{array}$ & $\begin{array}{l}7.4880 \\
15.10\end{array}$ & $\begin{array}{l}8.7775 \\
15.19 \\
\end{array}$ & $\begin{array}{l}9.7136 \\
16.38\end{array}$ & $\begin{array}{l}10.75 \\
17.35 \\
\end{array}$ & $\begin{array}{l}11.63 \\
18.20\end{array}$ & $\begin{array}{l}13.24 \\
19.49\end{array}$ & . \\
\hline Tukey's Hinges & $\begin{array}{l}\text { Total direct cost } \\
\text { of premix/meter square }\end{array}$ & $\begin{array}{l}\text { ACW20 } \\
\text { SMA }\end{array}$ & & & $\begin{array}{l}9.7396 \\
165.50\end{array}$ & $\begin{array}{l}10.75 \\
17.35\end{array}$ & $\begin{array}{l}11.61 \\
18.00\end{array}$ & & \\
\hline
\end{tabular}


Am. J. Applied Sci., 2 (9): 1350-1355, 2005

Table 3: Model summary table for SMA

\begin{tabular}{lcccc}
\hline Model & $\mathrm{R}$ & $\mathrm{R}$ square & Adjusted R square & Standard Error of the estimate \\
\hline 1 & $0.962^{\mathrm{a}}$ & 0.926 & 0.817 & 4.85333 \\
2 & $0.981^{\mathrm{b}}$ & 0.963 & 0.952 & 3.67871 \\
\hline
\end{tabular}

a. Predictors: (Constant), Material cost/ton

b. Predictors: (Constant), Material cost/ton, Transportation cost/ton

c. Dependent variable: Total direct cost of premix/ton

Table 4: Coefficient's table for SMA

\begin{tabular}{|c|c|c|c|c|c|c|c|}
\hline \multirow[t]{2}{*}{ Model } & \multicolumn{2}{|c|}{ Unstandardized coefficients } & Standardized coefficients & \multirow[t]{2}{*}{$\mathrm{t}$} & \multirow[t]{2}{*}{ Sig. } & \multicolumn{2}{|c|}{ Collinearity statistics } \\
\hline & B & $\mathrm{SE}$ & Beta & & & Tolerance & VIF \\
\hline 1 (Constant) & 74.017 & 9.776 & & 7.571 & 0.000 & & \\
\hline Material cost/ton & 0.723 & 0.072 & 0.962 & 10.012 & 0.000 & 1.000 & 1.000 \\
\hline 2 (Constant) & -59.459 & 51.262 & & -1.160 & 0.284 & & \\
\hline Material cost/ton & 1.005 & 0.120 & 1.383 & 8.348 & 0.000 & 0.207 & 4.841 \\
\hline Transportation cost/ton & 12. 498 & 4.750 & 0.422 & 2.631 & 0.034 & 0.207 & 4.841 \\
\hline
\end{tabular}

a. Dependent variable: Total direct cost of premix/ton

Thirdly, the data will be analyzed via regression analysis for the purpose of identifying the significant cost factor. According to Table 3, the Adjusted R Square values for SMA in Model 1 and Model 2 are more than 0.90 indicating that more than $90 \%$ variation in Construction cost/ton (dependent variable) is explained by Material cost/ton and Transportation cost/ton (predictor variables). However, Table 4 revealed that the $p$ value of the Model 1 is highly significant at 0.0001 while the $t$ statistics is relatively large at 10.012 indicating that there is a significant correlation between Construction cost/ton and Material cost/ton. Thus, the most significant factor in the Construction cost of SMA is Material cost/ton.

On the other hand, Table 5 which represents Model Summary for ACW20 revealed that only the Adjusted $\mathrm{R}$ Square value of the Model 3 is more than 0.90 indicating that more than $90 \%$ variation in Construction cost/ton (dependent variable) is explained by Material cost/ton, Transportation cost/ton and Plant cost/ton (predictor variables). Hence, Table 6 shows that Material cost/ton (Beta $=0.550)$ is making the most significant contribution towards the estimation of construction cost of ACW20. This is followed by Transportation cost/ton (Beta=0. 534) and Plant cost/ton (Beta=0. 430). The positive Beta coefficient values also indicate that there are positive linear relationship between the predictors and the dependent variable. Therefore, the most significant factors in the construction cost of ACW20 are Material cost/ton, followed by Transportation cost/ton and Plant cost/ton.

\section{DISCUSSION}

Based on the result obtained from the regression analysis performed earlier, the significant factor in the Construction cost of SMA is Material cost/ton while the 3 significant factors in the construction cost of ACW20 are (in sequence) Material cost/ton, Transportation cost/ton and Plant cost/ton. However, in order to produce a fair and square comparison, the number of significant cost elements for both SMA and ACW20 will have to be equal. Thus, the most significant factor in the Construction cost of SMA and ACW20 is Material cost/ton.

Mock-up study for an economic construction cost of SMA: Even though the construction cost of SMA is indeed significantly higher than ACW20, the research would like to initiate a solution that will make the construction cost of SMA more economical. First, the basic formula for calculating the Construction cost/meter square of the two design mixes is generated using the significant factor, which is Material cost/ton. Formula 1 displays this basic formula:

Formula 1: Basic formula for the significant construction cost

Formula: Construction

Cost of premix $=$ Material cost $\mathrm{x}$ Density $\mathrm{x}$ Thickness

Unit: $\quad\left(R M / m^{2}\right) \quad\left(R M /\right.$ ton $x$ ton $\left./ m^{3} \times m\right)$

Second, some logical but mock-up values must be generated and applied in the formula of Formula 1. The above formula contains three factors: Material cost, Density and Thickness. For the purpose of study, the values for Material cost will be represented by means, 5\% trimmed mean, median, maximum and maximum which were extracted from the descriptive statistics of 27 members of SMA and ACW20 projects. Meanwhile, the Density (in ton $/ \mathrm{m}^{3}$ ) for each design mix will be represented by a constant value of 2.35 ton $\mathrm{m}^{-3}$. This is based on current practice on the average forecasted field density for both SMA and ACW20. Finally, the value of Thickness of individual Material cost/ton will be in the range between 30 to $60 \mathrm{~mm}$ (or $0.030 \mathrm{~m}$ to $0.060 \mathrm{~m}$ ). This is in accordance to a study conducted by Muniandy ${ }^{[23]}$ on the threshold of surfacing layer thickness in 2.55 millions of standard axle load environment. The mock-up values of these three items are then listed and summarized in Table 7. 
Am. J. Applied Sci., 2 (9): 1350-1355, 2005

Table 5: Model summary table for ACW20

\begin{tabular}{lcccc}
\hline Model & $\mathrm{R}$ & R square & Adjusted R square & Standard Error of the estimate \\
\hline 1 & $0.690^{\mathrm{a}}$ & 0.476 & 0.441 & 5.62891 \\
2 & $0.813^{\mathrm{b}}$ & 0.662 & 0.613 & 4.68402 \\
3 & $0.961^{\mathrm{c}}$ & 0.924 & 0.906 & 2.30503 \\
\hline
\end{tabular}

a. Predictors: (Constant), Plant cost/ton

b. Predictors: (Constant), Material cost/ton

c. Predictors: (Constant), Material cost/ton, Transportation cost/ton

d. Dependent variable: Total direct cost of premix/ton

Table 6: Coefficients table for ACW20

\begin{tabular}{|c|c|c|c|c|c|c|c|}
\hline \multirow[t]{2}{*}{ Model } & \multicolumn{2}{|c|}{ Unstandardized coefficients } & \multirow{2}{*}{$\begin{array}{c}\text { Standardized coefficients } \\
\text { Beta }\end{array}$} & \multirow{2}{*}{$\mathrm{t}$} & \multirow{2}{*}{ Sig. } & \multicolumn{2}{|c|}{ Collinearity statistics } \\
\hline & B & SE & & & & Tolerance & VIF \\
\hline 1 (Constant) & 82.990 & 5.081 & & 16.334 & 0.000 & & \\
\hline Material cost/ton & 1. 179 & 0.319 & 0.690 & 3.694 & 0.002 & 1.000 & 1.000 \\
\hline 2 (Constant) & 53.294 & 11.531 & & 4.622 & 0.000 & & \\
\hline Plant cost/ton & 0.975 & 0.276 & 0.571 & 3.535 & 0.003 & 0.928 & 1.077 \\
\hline Material cost/ton & 0.619 & 0.224 & 0.447 & 2.768 & 0.015 & 0.928 & 1.077 \\
\hline 3. (Constant) & 37.477 & 6.147 & & 6.097 & 0.000 & & \\
\hline Plant cost/ton & 0.734 & 0.140 & 0.430 & 5.231 & 0.000 & 0.867 & 1.153 \\
\hline Material cost/ton & 0.763 & 0.112 & 0.550 & 6.801 & 0.000 & 0.894 & 1.118 \\
\hline Transportation cost/ton & 1. 090 & 0.163 & 0.534 & 6.694 & 0.000 & 0.920 & 1.087 \\
\hline
\end{tabular}

a. Dependent variable: Total direct cost of premix/ton

Table 7: Values of the three items required in the calculation

\begin{tabular}{|c|c|c|c|}
\hline Item & Sub-item & SMA & ACW20 \\
\hline Material cost & $\begin{array}{l}\text { Mean } \\
5 \% \text { Trimmed Mean } \\
\text { Median } \\
\text { Minimum } \\
\text { Maximum } \\
\end{array}$ & $\begin{array}{l}\text { RM 133.80 ton } \\
\text { RM } 133.52 \text { ton }^{-1} \\
\text { RM130.10 ton } \\
\text { RM 102.29 ton } \\
\text { RM } 170.32 \text { ton }^{-1} \\
\end{array}$ & $\begin{array}{l}\text { RM 53.00 ton } \\
\text { RM 52.55 ton } \\
\text { RM 52.16 ton } \\
\text { RM 47.38 ton } \\
\text { RM } 66.60 \text { ton }^{-1} \\
\end{array}$ \\
\hline Thickness & & $\begin{array}{l}0.030 \mathrm{~m} \\
0.035 \mathrm{~m} \\
0.040 \mathrm{~m} \\
0.045 \mathrm{~m} \\
0.050 \mathrm{~m} \\
0.055 \mathrm{~m} \\
0.060 \mathrm{~m}\end{array}$ & $\begin{array}{l}0.030 \mathrm{~m} \\
0.035 \mathrm{~m} \\
0.040 \mathrm{~m} \\
0.045 \mathrm{~m} \\
0.050 \mathrm{~m} \\
0.055 \mathrm{~m} \\
0.060 \mathrm{~m}\end{array}$ \\
\hline Density & & 2.35 ton $\mathrm{m}^{-3}$ & 2.35 ton $\mathrm{m}^{-3}$ \\
\hline
\end{tabular}

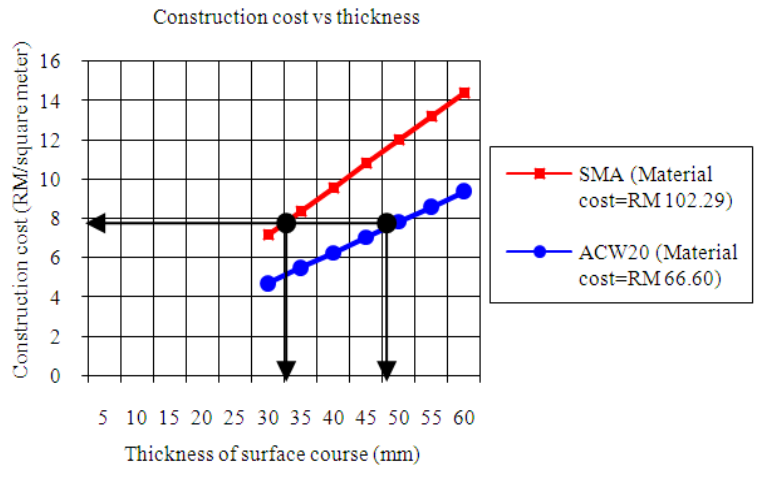

Fig. 2: Construction cost versus thickness chart for SMA and ACW20

Thirdly, the construction cost of SMA and ACW20 were then calculated based on the values displayed in Table 7. Observation on the result revealed that the Minimum Material cost of SMA is able to produce a feasible significant construction cost when laid at the minimum thickness of $30 \mathrm{~mm}$. This value is comparable to the construction cost of ACW20 using the Maximum value in Material cost and laid at the thickness of $50 \mathrm{~mm}$.

These Minimum scores on SMA's Material cost and the Maximum score on ACW20's Material cost were then transferred to a chart of Construction Cost versus Thickness, as illustrated in Figure 2. The chart indicates that the slope of SMA is steeper than the ACW20's slope. Thus, it is clear that the construction cost of SMA is highly influenced by both the material cost and its thickness. While the construction cost of ACW20 is highly influenced by its thickness rather than the material cost. Based on this finding, it is suggested that an economical construction cost of SMA may be possible if the material cost and thickness of the mix are properly weighted and balanced.

\section{CONCLUSION}

It is concluded that the construction cost of SMA is indeed significantly higher than ACW20 as reported by the exploratory data analysis result. Thus, the construction cost of SMA is not $10 \%$ to $15 \%$ less than ACW20 as claimed by a previous study by University 
Putra Malaysia ${ }^{[1]}$. Based on the mock-up study on the significant cost factor, it is revealed that Material cost and Thickness of the surfacing layer are the most influential factors in the construction cost of SMA. Thus, it may be possible to produce an economical construction cost of SMA as long as the weight between the material cost and thickness of the mix are properly balanced. Therefore the research recommends for future study to develop a universal model for estimating the future construction cost of SMA and ACW20.

\section{ACKNOWLEDGEMENT}

Firstly, we would like to thank all the respondents who were involved in this research especially the professionals in the quarrying industry in the Selangor state as well as road authorities such as the Public Works Department (JKR), Highway Planning Unit (HPU), Malaysian Board of Highway (LLM) as well as Ikram's Paves Sdn. Bhd. Last but not least, we would like to thank the Malaysian Ministry of Education and University Putra Malaysia for funding this research and publication. Thank you for your technical support and financial aid.

\section{REFERENCES}

1. UPM's Road Safety Research Center, 2000. Stone Mastic Asphalt (SMA) Technology with oil palm fiber for Malaysian roads. Unpublished poster. University Putra Malaysia, Malaysia.

2. Yu, J., 2000. Stone Mastic Asphalt pavement technology for the new millennium. The 4th Malaysian Road Conf. Kuala Lumpur: REAAM.

3. Nicholls, C., 1998. Asphalt Surfacings. 1st edn. London: E \& FN Spon.

4. Brown, E.R., R.B. Mallick, J.E. Haddock and J. Bukowski, 1997. Performance of stone mastic asphalt (SMA) mixtures in the United States. National Center of Asphalt Technology Report no 97-1. Alabama: Auburn University.

5. Vasudevan, J., R. Muniady, O. Husaini and R.S. Radin Omar, 2000. Cellulose oil palm fiber (COPF) in stone mastic asphalt for Malaysian roads. Proc. 4th Malaysian Road Conf. Kuala Lumpur: REAAM.

6. Muniady, R., S. Ali and O. Husaini, 2000. Laboratory evaluation of cellulose oil palm fiber for stone mastic asphalt mixes. Intl. J. Pavements, 1: 13-21.

7. Mohamad Razali, O. and S. Zulakmal, 2004. Innovative pavements in Malaysia. ISTAC Conf., Ikram, Malaysia.
8. Herbsman, Z., 1986. Model for forecasting highway construction cost. Transportation Research Record 1056, Transportation Research Board, Washington, D.C., pp: 47-54.

9. Stevens, J.D., 1995. Cost estimating and forecasting for highway work in Kentucky. Research Representative KTC 95-12, Kentucky Transportation Center, University of Kentucky, Lexington, Kentucky.

10. Kopulla, S.D., 1981. Forecasting engineering costs: Two case studies. J. Const. Div., Am. Soc. Civil Engineers, 107: 733-743.

11. Hartgen, D.T., V.B. Bowmana and M.W. Horner, 1997. Baseline market forecasts for state highway construction engineering, maintenance and administration programs 1997-2000. Transportation Publication Number 151, Center for Interdisciplinary Transportation Studies, University of North Caroline, Charlotte, N.C.

12. Wilmot, C.G. and G. Cheng. Estimating future highway construction costs. J. Const. Engg. Manag., 129: 272-279.

13. Williams, T.P., 2003. Predicting the final cost for competitively bid construction projects using regression models. Intl. J. Project Manag., 21: 593599.

14. Jin, F.S. and T.C Wei, 2003. A method to determine contract bids for incentive highway projects. Intl. J. Project Manag., 21: 601-615.

15. Williams, T.P., 2002. Predicting the completed project cost using bidding data. Constr. Manag. Economy.. 20: 225-235.

16. Hergazy, T. and A. Ayed, 1998. Neural network model for parametric cost estimation of highway projects. J. Constr. Engg. Manag., 124: 210-218.

17. Adeli, H. and M. Wu, 1998. Regularization neural network for construction cost estimating. J. Constr. Engg. Manag., 124: 18-24.

18. Herbsman, Z., 1986. Model for forecasting highway construction cost. Transportation Research Record 1056, Transportation Research Board, Washington, D.C., pp: 47-54.

19. Morrison, 1984. The accuracy of quantity surveyors' cost estimating.

20. Ashworth, A., 1995. Cost Studies of Buildings. 2nd Edn. United Kingdom: Longman.

21. Akintoye, A. and E. Fitzgerald, 2000. A survey of current cost estimating practices in the UK. Constr. Manag. Economy., 18: 161-172.

22. Oberlender, G.D. and S.M. Trost, 2001. Predicting accuracy of early cost estimates based on estimate quality. J. Constr. Engg. Manag., 127: 173-182.

23. Muniandy, R., 2000. Cost Benefit Analysis of SMA. Unpublished report, University Putra Malaysia, Malaysia. 